УДК [378.091.212:004]:004.92:005.336.2

DOI:

Ганна Чемерис, аспірант, викладач-стажсист кафедри інформатики і кібернетики Мелітопольського державного педагогічного університету імені Б. Хмельницького

\title{
ПОНЯТТЯ ГРАФІЧНОЇ КОМПЕТЕНТНОСТІ МАЙБУТНЬОГО БАКАЛАВРА 3 КОМП'ЮТЕРНИХ НАУК У ВІТЧИЗНЯНИХ ТА ЗАКОРДОННИХ ДОСЛІДЖЕННЯХ
}

У статті розглянуто теоретичний аналіз значення графічної компетентності. Досліджено основні наукові положення вітчизняних та закордонних вчених щуодо формування графічної компетентності, як важливої складової професійного становлення фахівців у системі вищої освіти. Проведено аналіз сучасних підходів, висвітлених у вітчизняних та закордонних джерелах, щзодо визначення сутності поняття “графічна компетентність”, як складової якісної підготовки фахівця. Закцентовано увагу на затребуваності формування графічної культури у майбутніх бакалаврів з комп ютерних наук, на основі чого подасться особистий погляд на визначення графічної компетентності як складової якісної професійної підготовки конкурентоспроможних майбутніх бакалаврів з комп'ютерних наук в умовах педагогічного вищого навчального закладу з урахуванням сучасних соиіальних процесів.

Ключові слова: графічна компетентність; графічна підготовка; майбутній бакалавр з комп'ютерних наук.

תim. 15.

Hanna Chemerys, Postgraduate Student, Lecturer-Trainee of the Computer Science and Cybernetics Department Melitopol Bohdan Khmelnitskiy State Pedagogical University

\section{THE CONCEPT OF GRAPHIC COMPETENCE OF THE FUTURE BACHELOR OF COMPUTER SCIENCE IN THE NATIVE AND FOREIGN RESEARCH}

The article is devoted to the theoretical analysis of the value of graphic competence. The basic scientific positions concerning the formation of graphic competence as an important component of the professional formation of specialists in the system of higher education of Ukraine are considered. The analysis of modern approaches, highlighted in the native and foreign sources, concerning the definition of the essence of the concept "graphic competence" as a component of qualitative training of a specialist has been carried out. The author emphasizes the demand of the formation of graphic culture of the future bachelors of computer sciences, on the basis of which the author's view on the definition of graphic competence as a component of qualitative professional training of competitive future bachelors on computer sciences in the conditions of a pedagogical institution of higher education, taking into account the modern social processes. The urgency of forming of graphic competence is also substantiated by its role in education, development and upbringing, namely, in the development of thinking, cognitive abilities and spatial imagination of future bachelors of computer sciences, the development of practical skills. Due to the fact that the target preparation of the Bachelor of Computer Science is aimed at training highly skilled professionals, then each graduate of this profile must have a wide range of basic knowledge, skills and abilities in computer graphics and design for effective presentation of the developed Software to the end user. The results of the analysis of the scientific experience of the mentioned authors, we have determined that graphic competence is versatile, and includes not only the features inherent in artistic or creative activity, but also solid knowledge and skills of the technical component, which are rapidly expanding and branching in view of rapid pace of development of computer technology and modernization of graphic tools.

Keywords: graphic competence; graphic preparation; a future bachelor of computer sciences.

П остановка проблеми. Сьогодні, під час чергового еволюційного стрибку утехнологічномурозвиткуінформаційної сфери та уграфічномууявленні інформаціїнеможливо уявити будь-якусистемучи програму без належного графічного інтерфейсу. Також все щільніше у побут входять технології віртуальної реальності, тривимірного друку та сканування, існування яких і взагалі не можливе без належного візуального представлення та супроводу. Тому затребуваною на ринку праці стає якість професіоналів з високим рівнем графічної підготовки. Зважаючи на це, приділення уваги графічній освіті майбутніх бакалаврів 3 комп'ютерних наук та запровадження графічної підготовки у процес професійної освіти стає пріоритетним напрямком. Таким чином постає проблема змісту професійної графічної освіти майбутніх бакалаврів 3 комп'ютерних наук.

Аналіз останніх досліджень та публікацій. На сучасному етапі розвитку педагогічної думки багато закордонних та українських учених 


\section{ПОНЯТТЯ ГРАФІЧНОЇ КОМПЕТЕНТНОСТІ МАЙБУТНЬОГО БАКАЛАВРА З КОМП'ЮТЕРНИХ НАУК У ВІТЧИЗНЯНИХ ТА ЗАКОРДОННИХ ДОСЛІДЖЕННЯХ}

досліджували різні аспекти графічної підготовки студентів: Л. Халім (L. Halim) [15], А. Діспанд (A. Despande) [14], О. Джеджула [3], О. Конопля [7], М. Ожга [9], Л. Шкіца [13] та ін. Окремі аспекти удосконалення методики викладання графічних дисциплін висвітлені у працях Н. Бондар [1], О. Джеджули [3], Г. Райковської [10] й інших науковців.

Метою статті є дослідження поняття “графічна компетентність” у закордонній та вітчизняній науковій літературі.

Виклад основного матеріалу. Нова парадигма вищої освіти, що зумовлена структурною перебудовою економіки Української держави, іiі інтеграція до європейського співтовариства, впровадження новітніх технічних засобів призвело до того, що сучасна освіта повинна бути спрямована на формування соціально значущих компетентностей, які відповідають змісту та динаміці соціально-економічних зрушень, що спричинені глобалізацією усіх суспільних процесів. Формування фахівця, як творчої особистості, здатного до саморозвитку, самоосвіти, інноваційної діяльності - одне 3 основних завдань вищої освіти.

За цих умов основними характеристиками майбутнього бакалавра комп'ютерних наук має стати не лише професіоналізм, а й компетентність, самоорганізація та креативність. Інтерес роботодавця на ринку праці нині представляє спеціаліст технічного профілю, що володіє професійними компетентностями, які відповідають рівню розвитку сучасних інформаційно-комунікаційних технологій.

Здійснений нами огляд запитів ринку праці свідчить про те, що роботодавці пред'являють ряд вимог до рівня підготовки молодих спеціалістів [12,74-76], чим стимулюють суттєве оновлення змісту сучасної підготовки майбутніх бакалаврів 3 комп'ютерних наук. Роботодавці вимагають від випускників вищих навчальних закладів, майбутніх бакалаврів комп'ютерних наук, адаптованості та гнучкості щодо зміни видів та способів професійної діяльності з урахуванням сучасного стану та перспектив розвитку виробництва. Так сучасні тенденції ринку праці України зумовлюють зростання затребуваності фахівців з прогресивним рівнем професійної підготовки, що базується на знанні комп'ютерного інструментарію для роботи 3 комп'ютерною графікою та базовим знанням комп'ютерного дизайну.

Від професіонала у галузі комп'ютерних наук нині вимагається вміння швидко проектувати якісний та ергономічний графічний інтерфейс програмного продукту чи інформаційної системи, моделювати та проектувати тривимірну чи анімаційну графіку, мати творчий підхід до презентації власного програмного продукту для досягнення гармонії змісту та форми, що за сукупності передбачає високий рівень сформованої графічної компетентності. Це ставить перед науковцями й освітянами завдання зробити професійне навчання майбутніх бакалаврів 3 комп'ютерних наук гнучким, адаптованим до потреб роботодавців щодо формування графічної компетентності. В. Моркун, 3. Бакум наголошують, що одним із напрямів професійної підготовки інженера є фундаментальна підготовка, основне завдання якої полягає у формуванні проектноконструкторської компетентності та всебічному розвитку студента як особистості, який прагне подальшого збагачення та зростання свого освітнього потенціалу [8, 111].

Отже, у сучасній системі освіти майбутнього бакалавра 3 комп'ютерних наук графічна компетентність повинна розглядатись як необхідна умова готовності фахівця до професійної діяльності. Розглянемо детальніше сугність понять графічної компетентності, що наведені у наукових працях вітчизняних та закордонних науковців.

Графічна компетентність за визначенням П. Буянова $є$ однією $з$ важливих властивостей особистості та рівень усвідомленого використання графічних знань, умінь і навичок, що спираються на знання функціональних і конструктивних особливостей технічних об’єктів, досвід графічної професійно-орієнтованої діяльності, вільну орієнтацію в середовищі графічних інформаційних технологій $[2,174]$.

Графічна компетентність розглядається у роботі О. Коваленко як предметно-спеціалізована, 3 акцентом на компетенції в галузі комп'ютерних технологій. Науковець стверджує, що графічна компетентність відображає інтеграційні тенденції сучасного розвитку освіти, та наголошує на тому, що зміст графічної компетентності не має бути статичним, а повинен систематично коригуватися, відображати рівень розвитку техніки і технології. Графічна компетентність повинна вказувати загальні вимоги для підготовки фахівця, а іï формування має ряд особливостей та грунтується на взаємодії теоретичних знань і практичних умінь, спираючись на досвід. Від так компетентним фахівцем можливо стати лише через практичну діяльність [5, 128].

Розглядаючи графічну компетентність, Ю. Козак визначає їі як сукупність базових 


\section{ПОНЯТТЯ ГРАФІЧНОЇ КОМПЕТЕНТНОСТІ МАЙБУТНЬОГО БАКАЛАВРА З КОМП'ЮТЕРНИХ НАУК У ВІТЧИЗНЯНИХ ТА ЗАКОРДОННИХ ДОСЛІДЖЕННЯХ}

графічних знань та умінь, а також емоційної інтелігентності, помножених на креативність у сукупності з самовдосконаленням (розвитком) [6, 161].

Значна кількість науково-педагогічних досліджень була присвячена розгляду проблеми формування графічної компетентності мистецьких спеціальностей, проте невелика їх кількість робіт - вивченню проблеми формування графічної компетентності інженерних спеціальностей та спеціальностей педагогічного спрямування, i зовсім незначна кількість досліджень була спрямована на вивчення проблеми формування графічної компетентності у студентів спеціальностей, що пов'язані з інформаційними технологіями. Отже, проблема формування графічної компетентності в процесі професійної підготовки майбутнього бакалавра 3 комп’ютерних наук та безпосередньо процес навчання комп'ютерної графіки та дизайну бакалаврів 3 комп'ютерних наук спеціально не досліджувались, тому потребує грунтовного наукового пошуку.

Серед основних результатів графічної підготовки Н. Дорошенко виокремлює формування і розвиток у молодої людини “графічного" та безпосередньо творчого мислення, що інтегрує в собі окремі аспекти просторового, образного, візуального, проектувального та зокрема алгоритмічного мислення, здатність до абстрагування, аналізу і синтезу деякої просторової форми [4].

Проаналізований науковий досвід цих авторів дозволив нам виявити такі психічні процеси, що виступають як важливі функціональні і операційні механізми графічної діяльності: зорове сприйняття (розмірів, протяжних властивостей предметів, відстаней між предметами); окомір (лінійний, об'ємний, кутовий, просторовий, динамічний, на малі відстані); уявлення (зорове, просторове, фігур і форм); уяву (просторове); мислення (наочно-образне, логічне, абстрактнологічне, оперативне, технічне, комбінаторні здатності); пам'ять зорова (короткочасна, довготривала, оперативна). Ми підтримуємо тезу про те, що “процес формування графічних понять має відбуватися в результаті системного поєднання перцептивної, абстрактно-логічної та чуттєво-практичної діяльності" [4].

Подані вище дефініції і методологічні напрацювання дослідників педагогічної освіти вплинули на загальне розуміння графічної компетентності, розглянувши які даємо власне визначення поняття графічної компетентності майбутніх бакалаврів комп 'ютерних наук [11], як інтегративної властивості, що включає вміння здійснювати якісну організацію та проектування програмних засобів, професійно використовувати сучасні комп'ютерні графічні технології під час проектування інтерфейсу розроблюваного програмного засобу, знаходити оптимальні технології досягнення кращого результату 3 урахуванням ергономічних вимог кінцевої аудиторії, тобто користувачів засобу чи споживачів продукту.

Проблема критичної залежності суспільства від якісної візуальної подачі програмного продукту в умовах відносної необізнаності програмної інженерії у базових естетично-художніх принципах робить питання формування графічної компетентності ще більш важливим для підготовки для майбутніх бакалаврів комп'ютерних наук. Відповідно фахівцям 3 комп'ютерних наук необхідно приходити на робоче місце підготованими як до вирішення завдань $з$ програмування, так і до необхідності презентувати власний продукт за допомогою якісного та професійно опрацьованого його оформлення.

Відтак графічна компетентність, на нашу думку, є невід'ємною складовою професійної підготовки майбутніх бакалаврів комп'ютерних наук у вищих навчальних закладах. Хоча і не передбачається, що майбутній бакалавр 3 комп'ютерних наук володіє повним спектром знань в усіх аспектах художньо-мистецької діяльності, загальне розуміння їх застосування та осмислення базових концепцій, таких, як наприклад, композиція, є абсолютно необхідною умовою професіоналізму, адже проектування інтерфейсу розробленого програмного забезпечення $є$ важливою складовою проектної діяльності та відіграє важливу роль під час розробки програмного забезпечення. Цю підготовку можливо здійснювати у рамках вивчення такого циклу дисциплін, як “Комп'ютерна графіка" та “Основи комп'ютерного дизайну” з метою формування графічної компетентності, розвитку професійної майстерності, творче зростання та естетичного виховання особистості програміста.

Висновки і перспективи подальших досліджень. У результаті проведеного дослідження та аналізу поставленої проблеми можемо зробити висновок, що графічна компетентність, хоча і $є$ притаманною будь-якій особистості, проте не розвивається та не вдосконалюється самостійно, тому іiї необхідно формувати та розвивати з урахуванням специфіки професійної діяльності майбутнього бакалавра з комп'ютерних наук. 


\section{ПОНЯТТЯ ГРАФІЧНОЇ КОМПЕТЕНТНОСТІ МАЙБУТНЬОГО БАКАЛАВРА З КОМП'ЮТЕРНИХ НАУК У ВІТЧИЗНЯНИХ ТА ЗАКОРДОННИХ ДОСЛІДЖЕННЯХ}

Актуальними напрямами подальшого наукового пошуку вважаємо виявлення сучасних педагогічних засад з метою формування графічної компетентності майбутніх бакалаврів комп'ютерних наук нової генерації, здатних до ефективної професійної діяльності, що $\epsilon$ важливою складовою їхнього подальшого професійного зростання.

\section{ЛІТЕРАТУРА}

1. Бондар Н. О. Дидактичні умови активізації мислительної діяльності учнів 8-9 класів на уроках креслення: дис. ... канд. пед. наук: 13.00.02 / Н. О. Бондар. - Чернігів, 2006. - 236 с.

2. Буянов П. Г. Ступінь і складові графічної професійної компетентності майбутніх учителів технології / П. Г. Буянов // Наукові записки ТНПУ ім. В. Гнатюка. Серія. Педагогіка. - 2010. - № 1. - C. 171-175.

3. Джеджула О. М. Теорія і методика графічної підготовки студентів інженерних спеціальностей вищих навчальних закладів: дис. ... д-ра пед. наук: 13.00.04 / О. М. Джеджула. - К., 2007. - 460 с

4. Дорошенко Н. І. Педагогічні умови формування понять у процесі графічної підготовки майбутніх кваліфікованих робітників будівельного профілю //Професійне становлення особистості: проблеми і перспективи. - 2007. С. 330-338.

5. Коваленко А. В. Графическая компетенция как одна из составляющих профессиональной компетентности бакалавра профессионального обучения по направлению 051000.62 Профессиональное обучение (по отраслям)// Вестник Челябинского государственного педагогического университета. - 2011. - №. 10.

6. Козак Ю. Ю. Графічна компетентність як складова професійної підготовки майбутніх інженерів-педагогів комп'ютерного профілю / Ю. Ю. Козак // Наукові записки. Серія: педагогіка, №2, 2016. - стр. 158-163.

7. Конопля О. В. Проблеми та значення графічної підготовки майбутніх інженерів залізничного транспорту / О. В. Конопля // Єдність навчання і наукових досліджень головний принцип університету: [збірник наукових праць звітно-наукової конференції викладачів університету за 2012 рік, 9 - 10 лютого 2013 року]. - К.: Вид-во НПУ ім. М. Драгоманова, 2013. - С. 20-22

8. Моркун В. С. Проблеми формування проектно-конструкторської компетентності гірничого інженера в процесі графічної підготовки / [Моркун В. С., Бакум 3. П., Цвіркун Л. О.] // Science and Education a New Dimension: Pedagogy and Psychology - II (8). - Issue: 16. - 2014. C. 110-114.

9. Ожга М. М. Проблеми графічної підготовки майбутніх інженерів-педагогів у наукових дослідженнях / М. М. Ожга // Проблеми інженерно-педагогічної освіти : [збірник наук. праць] / Укр. інж.-пед. академія. - 2012. - Вип. 34-35. - С. 226-233.

10. Райковська Г. О. Наукові підходи та сучасний стан $з$ графічної підготовки майбутніх фахівців у ВНЗ / Г. О. Райковська // Вісник Житомирського державного університету ім. I. Франка. - 2007. - № 35. - С. 109-114.

11. Чемерис Г. Ю. Аналіз сутності поняття “графічна компетентність” у системі підготовки майбутнього бакалавра 3 комп'ютерних наук / К. П. Осадча, Г. Ю. Чемерис // Ukrainian Journal of Educational Studies and Information Technology, Vol. 5, №. 3, (2017) . - Стр. 37-46.

12. Чемерис Г. Ю. Добір засобів тривимірного моделювання для процесу формування графічної компетентності майбутніх бакалаврів 3 комп'ютерних наук / К. П. Осадча, Г. Ю. Чемерис // Інформаційні технології і засоби навчання (Information Technologies and Learning Tools): електронне наукове фахове видання [Електронний ресурс] / Ін-т інформ. технологій i засобів навчання АПН України, Ун-т менеджменту освіти АПН України; гол. ред. В.Ю. Биков. - 2017. - T. 6, №62. - С. 70-85.

13. Шкіца Л. Є. Організація самостійної роботи студентів із графічних дисциплін / [Шкіца Л. Є., Тарас I. П., Корнута О. В.] // Збірник наук. праць “Современные тенденции в науке и образовании”, Варшава. - 2014. - С. 10-11.

14. Deshpande A. Use of Educational Technology in Engineering Education / A. Deshpande // WSEAS Transactions on Advances in Engineering Education. - Issue 8. - Vol. 7. - 2010. - P. 245-154.

15. Halim L. Innovative Communication Tool in Teaching Engineering Drawing / [Halim L., Yasin R., Ishar A.] // WSEAS Transactions of Information Science and Application. - Issue 2. - Vol. 9. - 2012. - P. 58-67.

\section{REFERENCES}

1. Bondar, N. O. (2006). Dydaktychni umovy aktyvizatsii myslytelnoi diialnosti uchniv 8-9 klasiv na urokakh kreslennia [Didactic conditions for activating the thinking activity of pupils of grades 8-9 at the lessons of the drawing]. Candidate's thesis. Chernihiv, 236 p. [in Ukrainian].

2. Buyanov, P. G. (2010). Stupin i skladovi grafichnoyi profesijnoyi kompetentnosti majbutnix uchyteliv texnologiyi [Degree and graphic components 


\section{ПОНЯТТЯ ГРАФІЧНОЇ КОМПЕТЕНТНОСТІ МАЙБУТНЬОГО БАКАЛАВРА З КОМП'ЮТЕРНИХ НАУК У ВІТЧИЗНЯНИХ ТА ЗАКОРДОННИХ ДОСЛІДЖЕННЯХ}

of professional competence of future teachers of technology]. Scientific Notes of TNPU them. V. Hnatyuk. Series. Pedagogy, Ternopil. Vol 1. pp. $17-175$. [in Ukrainian].

3. Dzhedzhula, O. M. (2007). Teoriia i metodyka hrafichnoi pidhotovky studentiv inzhenernykh spetsialnostei vyshchykh navchalnykh zakladiv [Theory and methods of graphic preparation of students of engineering specialties of higher educational institutions]. Doctor's thesis. Kyiv, 460 p. [in Ukrainian].

4. Doroshenko, N. I. (2007). Pedahohichni umovy formuvannia poniat $\mathrm{u}$ protsesi hrafichnoi pidhotovky maibutnikh kvalifikovanykh robitnykiv budivelnoho profiliu [Pedagogical conditions of the formation of concepts in the process of graphic training of future skilled construction workers]. Professional formation of the person: problems and perspectives. pp. 330338. [in Ukrainian].

5. Kovalenko, A. V. (2010). Hrafycheskaia kompetentsyia kak odna yz sostavliaiushchykh professyonalnoi kompetentnosty bakalavra professyonalnoho obuchenyia po napravlenyiu 051000. 62 Professyonalnoe obuchenye (po otrasliam) [Graphic competence as one of the components of the professional competence of the bachelor of professional training in the direction of 051000. 62 Professional training (by branch)]. The Bulletin of the Chelyabinsk State Pedagogical University, no. 10, pp. 83-95. [in Ukrainian].

6. Kozak, Iu. Iu. (2016). Hrafichna kompetentnist yak skladova profesiinoi pidhotovky maibutnikh inzheneriv-pedahohiv kompiuternoho profiliu [Graphic competence as a component of the training of future engineer teachers of the computer profile]. Scientific notes. Series: Pedagogy, vol. 2. p. 158-163. [in Ukrainian].

7. Konoplia, O. V. (2013). Problemy ta znachennia hrafichnoi pidhotovky maibutnikh inzheneriv zaliznychnoho transportu [Problems and meanings of graphic training of future railway engineers]. Unity of study and scientific research - the main principle of the university. Kyiv: Vyd-vo NPU im. M. Drahomanova, pp. 20-22. [in Ukrainian].

8. Morkun, V. S., Bakum, Z. P. \& Tsvirkun, L. O. (2014). Problemy formuvannia proektnokonstruktorskoi kompetentnosti hirnychoho inzhenera $\mathrm{v}$ protsesi hrafichnoi pidhotovky [Problems of formation of design and development competence of mining engineer in the process of graphic preparation].
Science and Education a New Dimension: Pedagogy and Psychology II (8), issue 16, pp. 110-114. [in Ukrainian].

9. Ozhha, M. M. (2012). Problemy hrafichnoi pidhotovky maibutnikh inzheneriv-pedahohiv u naukovykh doslidzhenniakh [Problems of graphic training of future engineers-teachers in scientific research]. Problems of engineering and pedagogical education: collection of sciences. works of Ukr. eng.ped. academy. Vol. 34-35. pp. 226-233. [in Ukrainian].

10. Raikovska, H. O. (2007). Naukovi pidkhody ta suchasnyi stan $\mathrm{z}$ hrafichnoi pidhotovky maibutnikh fakhivtsiv u VNZ [Scientific approaches and current state of graphic training of future specialists in higher educational institutions]. Bulletin of the I. Franko Zhytomyr State University no.35, pp. 109-114. [in Ukrainian].

11. Osadcha, K., \& Chemerys, H. (2017). Analiz sutnosti poniattia "hrafichna kompetentnist" u systemi pidhotovky maibutnoho bakalavra z kompiuternykh nauk [Analysis Of The Mention Of The Concept "Graphic Competence" In The Preparation Of The Future Bachelor Of Computer Science]. Ukrainian Journal of Educational Studies and Information Technology, vol.5(3), 37-46. [in Ukrainian].

12. Osadcha, K. P. \& Chemerys, H. Y. (2017). Dobir zasobiv tryvymirnoho modeliuvannia dlia protsesu formuvannia hrafichnoi kompetentnosti maibutnikh bakalavriv z kompiuternykh nauk [Threedimensional modeling tools in the process of formation of graphic competence of the future bachelor of computer science]. Information technologies and learning tools, vol.62(6). pp. 70-85. [in Ukrainian].

13. Shkitsa, L. Ie., Taras, I. P. \& Kornuta, O. V. (2014). Orhanizatsiia samostiinoi roboty studentiv iz hrafichnykh dystsyplin [Organization of independent work of students from graphic disciplines]. Collection of sciences. Works "Modern Trends in Science and Education”, Varshava. pp. 10-11. [in Ukrainian].

14. Deshpande, A. V. (2010). Use of Educational Technology in Engineering Education-A Computer Assisted Instruction (Multimedia) Package for Engineering Students. WSEAS Transactions on Advances in Engineering Education, 7(8), 245-254. [in English].

15. Halim, L., Yasin, R. M. \& Ishar, A. (2012). Camed: An innovative communication tool in teaching engineering drawing. WSEAS Transactions on Information Science and Applications. No. 9 (2). pp. 58-67. [in English].

Стаття надійшла до редакції 26.03.2018

\section{G5808

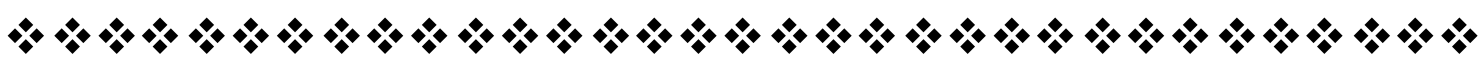

